\title{
Cancer Stem Cells in Human Prostate Cancer. Role in Drug Resistance and Metastasis
}

\author{
Las Células Troncales del Cáncer en el Cáncer de Próstata Humano. \\ Rol en la Resistencia a los Medicamentos y la Metástasis
}

\author{
Enrique A. Castellón* \& Héctor R. Contreras*
}

CASTELLón, E. A. \& CONTRERAS, H. R. Cancer stem cells in human prostate cancer. Role in drug resistance and metastasis. Int. J. Med. Surg. Sci., 2(4):711-722, 2015.

SUMMARY: Prostate cancer is one of the most important causes of oncologic death in men, and Chile has also reached that level. Prostate cancer mortality is mostly associated with metastatic disease where the cancer is usually resistant to available treatments, particularly hormone- therapy and chemotherapy. It has been suggested that the existence of cancer stem cells could account for the metastatic capacity and treatment resistance in most cancers. Recently, cells with stem characteristics have been identified in established cell lines and animal models of prostate cancer. We have isolated and characterized this kind of cells from patient tumors. This finding opens the possibility to manipulate them as potential therapeutic targets.

KEY WORDS: Prostate cancer; Cancer stem cells; Drug resistance; Metastasis.

\section{INTRODUCTION}

Prostate cancer (PCa) is a leading cause of cancer deaths in men worldwide (International Agency for Research of Cancer, 2012). In Chile, PCa has reached this level very quickly and over 1,400 patients die annually of this cancer in our country, which is equivalent to a rate exceeding 17 per 100,000 men (MINSAL). Because PCa is a condition that occurs primarily in men over 60 years, where other associated medical conditions may be contributing to the cause of death, the number of PCa death may be even underestimated. In Chile, PCa has been included in the AUGE plan from 2006 according to Decree 288 (DEIS, 2015). In the last years the number of cases has been reported at over 8,000 (DEIS), making this disease a major national public health problem. PCa can often be cured if it is localized, or can be controlled when it responds to current treatments, even when it is disseminated. Mortality for PCa is associated with metastatic disease when it becomes resistant to treatments (hormone therapy, radiotherapy and chemotherapy). The rate of tumor growth varies from very slow to moderately fast, which makes some patients having prolonged survival even after metastasis. However, this variability makes it very difficult to predict tumor behavior and to take the most appropriate therapeutic decision (Roussel et al., 2015). At present, the main diagnostic elements are the digital rectal examination and blood level of prostatic specific antigen (PSA). When one or both tests are positive, the patient is referred for a confirmatory biopsy. Moreover, the high variability in the prostate carcinoma behavior is a source of controversy in the clinical management of this cancer. Treatment options are based primarily on the stage of the cancer, which is not always easy to determine (Roussel et al.). The outcomes of the treatments that are now offered in medical oncology are determined by patient age, presence of other

*Laboratory of Molecular and Cellular Andrology. Physiology and Biophysics Program. Institute of Biomedical Sciences. Faculty of Medicine. Universidad de Chile, Santiago, Chile. 
medical conditions and degree of tumor differentiation. The treatments are as follows according to the disease status:

\section{Localized cancer (not spread):}

- Radical prostatectomy in patients younger than 70 years.

- Radiotherapy at low-level and locally applied (brachytherapy).

- Observation without treatment. For slowcourse disease. It should be monitored carefully (active surveillance).

Spread cancer:

- Hormone-therapy and chemotherapy.

The appropriate and timely therapeutic decision, especially in localized cancers where careful observation (watchful waiting) is commonly indicated, has a decisive impact on the cost-benefit for the patient, as tumors of the same histological grade may have very different evolution, and the time between diagnosis and therapeutic action can be decisive for the patient outcome. Even in the apparently curative treatments such as radical prostatectomy, in cases of localized carcinoma, patients may have a recurrence of over 25-35 \% (Van Poppel et al., 2009). Despite the usefulness of screening programs in increasing the early diagnosis, appropriate therapeutic decision in these cases is still severely constrained by the lack of suitable prognostic tools.

Recent scientific advances in the field of cancer are changing the view on the pathogenesis and progression of this disease and there is evidence that the presence of tumor stem-like cells could be influencing the key processes of tumor progression (Shipitsin \& Polyak et al., 2008). It has been demonstrated in several types of cancer, the existence of cancer stem cells (CSCs) populations that would account for the metastatic capacity, recurrence, and resistance to various treatments such as hormone, radio and chemotherapy that these cancers can develop (Gao, 2008; Ishii et al., 2008). In established cell lines from PCa origin, particularly from metastasis, it has been possible to identify these CSCs (Tang et al., 2007; Miki \& Rhim, 2008) and it would be very useful to evaluate their presence, type and amount in biopsies of patients diagnosed with localized and metastatic cancers. This analysis might represent an important prognostic tool, especially in relation to the metastatic potential of tumor, the possibility and timing of recurrence after surgery, and the timing of treatmentresistance development. This would allow to adequate the protocol and timing of therapies and possibly lay the groundwork for the development of new therapies aimed at the selective elimination of these CSCs.

\section{Cancer stem cells and metastasis}

Stem cells are defined on the base of selfrenewal capacity and the ability to giving rise different cell types that can develop an organ or tissue. Some stem cells (especially embryonic) are capable of developing into different types of tissues (pruripotentiality) (Reya et al., 2001; Glinsky, 2008; Cabanillas \& Llorente, 2009). The first evidence of the existence of CSCs originates from haematopoietic cancers nearly 10 years ago (Lapidot et al., 1994: Bonet \& Dick, 1997). Either normal and cancer stem cells have organogenesis capabilities, but normal stem cells originate normal organs or tissues and CSCs would generate malignant tissue with similar characteristics to those of the original tumor. The mechanisms of initiation and development of cancer remains difficult to understand despite all thedecades of progress in cancer research. The identification of CSCs in several types of cancer has challenged the hypothesis of "clonal evolution" for cancer development and could implicate a new pathway for new cancer treatments (Lewis, 2008; Filip et al., 2008; Gil et al., 2008). The recent identification of precancerous stem cells (pCSCs) as precursor cells of CSCs suggests that the stem cell hypothesis is not inconsistent with clonal evolution, but rather an aspect of it. It is not clear yet whether the CSCs are caused by a malignant transformation of normal stem cells or malignant cells, in their transformation process, progressively acquire stem cell characteristics (Ward \& Dirks, 2007; Lobo et al., 2007). Current evidence suggests that most cancers originate from progenitor cells (that originate from stem cells during the differentiation process), rather than stem cells themselves (Pardal et al., 2003). There is still a debate about the existence of a 
real stem cell in cancer, but it is rather a semantic than a biological discussion. It is perfectly possible that, as part of a "clonal evolution" process, a small population of cells regain some stem cell capabilities. Indeed, these cell populations with acquired "stemness" features can be considered as cancer stem-like cells. For all purposes of the present review, these cells will be called CSCs.

In humans, the vast majority of cancers are transformations of epithelial cells (carcinomas and adenocarcinomas) and a very small percentage corresponds to stromal cell malignancies (sarcomas). In general, it is well established that during the malignant transformation of epithelial cells key components that maintain their differentiated state are lost, such as adhesion molecules that regulate cellcell and cell-extracellular matrix interactions that are essential for position control (E-cadherin, syndecans, etc). Also, the cancer cells begin to express genes that confer them proliferative, migratory and invasive capacities among others. This series of changes known as epithelialmesenchymal transition (EMT) is quite well described for many types of cancer (Acloque et al., 2009). In our laboratory, we have studied several of these EMT markers and their relation to the recurrence of prostate cancer, highlighting syndecans 1 and 2, Snail, among others (Contreras et al., 2009; Poblete et al., 2014). The most common belief is that tumor cells that have undergone EMT are very aggressive because they can invade the underlying stroma, enter lymphatic and blood vessels, exit to blood circulation and, eventually, produce distant metastases. It is generally believed that solid tumors are more or less homogeneous groups of cells with high proliferative and invasive capacity and, in a stochastic way; some may leave the tumor and metastasize. This has resulted in that most cancer treatments are aimed at eliminating these cells (Le Tourneau et al., 2008). However, the identification of small populations of CSCs in various cancers and cancer established cell lines has been cause to re-evaluate the situation. The evidence suggests that the actual malignant cells able to colonize other tissues and, eventually, to produce secondary tumors (metastases) are the CSCs (Chiang \& Massagué, 2008). It is generally accepted that stem cells are resistant to cancer treatments due to their relatively low rate of proliferation, high rate of detoxification (high expression of transporters $A B C$ ), high rate of DNA repair and resistance to apoptosis. The CSCs also, unlike other non-stem tumor cells, have a high resistance to conventional cancer treatments as chemotherapy and radiotherapy (Borst et al., 2007).

It is known that metastasis is a very inefficient process because less than $1 \%$ of the neoplastic cells that come out into blood circulation may actually colonize other organs, and only a smaller percentage of them may produce metastases (Chiang \& Massagué). During the development of a primary tumor, the neoplastic cells secrete a number of altered proteins that circulate in the blood plasma. Some of them serve as warning signals to the immune system, but others, apparently in a selective way, affect specific stromal tissue in order to favoring CSCs niche (niche conditioning) (Wiltz, 2008). When CSCs come to colonize these conditioned stromas, they may remain for long periods (even years) in dormant state and then activate and produce metastases (Wels et al., 2008). This would explain the recurrence after apparently curative surgery in many cancers. In several cases, when a cancer is diagnosed as localized and without clinically evident metastases, it is believed that radical surgery is curative. However, at this state, many cancer cells may have gone out into blood circulation and some of them (presumably CSCs) may have colonized lymph nodes or other tissues and entered in this dormant state. These putative CSCs may be responsible for later recurrence in these patients. Since much of the cancer mortality is due to metastasis, the study of molecular and functional characteristics of the CSCs has been of increasing interest in the last years.

In PCa, suitable models for the actual role of CSCs in metastasis are needed. Recently, in our laboratory, we have developed an orthotopic model of human PCa in NOD/SCID immunocompromised mice (Cifuentes et al., 2015a, 2015b).

\section{Cancer stem cells in prostate cancer}

Prostatic epithelium consists basically of two epithelial compartments: the basal and luminal layers. In the basal layer two cell types 
are found: basal cells, which are more abundant, and neuroendocrine cells representing a minority. Into the luminal layer, secretory cells are found. These cell types are distinguished by their phenotypic and functional characteristics ( $\mathrm{Di}$ Zazzo et al., 2015). Secretory luminal cells express androgen receptor (AR), prostate specific antigen (PSA), prostatic acid phosphatase (PAP), CD57 and low molecular weight cytokeratins (K8 and $\mathrm{K} 18$ ).Basal cells are non-secretory and express CD44, p63 and high molecular weight cytokeratins ( $\mathrm{K} 5$ and $\mathrm{K} 14$ ), but do not express AR, PAP or PSA. Neuroendocrine cells express chromogranin A and several peptide hormones, but do not express AR or PSA. These cells originate from dendritic cells rather than epithelial cells and their function is not very clear (Timms, 2008). In the prostate, normal stem cells within the basal layer of the epithelium have been identified and it is proposed that these androgeninsensitive stem cells (not expressing AR) would give rise to other normal stem cells (self-renewal) and transition progenitor cells that then will give rise to luminal androgen-sensitive secretory cells. Androgens, particularly DHT, (the testicular testosterone is converted into DHT within the prostate cells by the 5 -alpha reductase) not only regulate the secretion of PSA but also the cell survival and tissue homeostasis in the prostate. This regulation also extends to cell proliferation in early stage of prostate cancer (Nelson et al., 2003). For this reason, therapeutic strategies based on androgen deprivation have been developed to treat prostate cancer. However, in advanced stages, prostate cancer cells are insensitive to androgens. Several mechanisms have been proposed for this androgen insensitivity, such as amplifications and activating mutations of RA gene, but the mechanism is still not completely understood (Shah et al., 2004; Roussel et a/.). Although most prostate cancer cells express $A R$, this expression is heterogeneous in both the primary tumor and in its metastases. This heterogeneity could be the key for understanding the progression of this cancer and for the development of future treatments. In this regard, the presence of CSCs that do not express RA could be an important point to consider. In recent years, several studies have reported CSCs identified in prostate cancer (Fioriti et al., 2008; Maitland and Collins, 2008; Masters et al., 2008; Kasper, 2008). The majority of them have used established cell lines originated from prostate cancer, mainly from metastasis, and animal models. These studies have identified several molecular markers for CSCs such as CD44, CD133, CD24, CD40 and $\alpha 2 \beta 1$ integrin, among others. In addition to these surface markers, the ability to exclude Hoechst 33342 staining has been widely used for identifying and separating stem cells (Patrawala et al., 2005). The exclusion of this dye is caused by the ABCG2 transporter that is over-expressed in this cell type. Recently the presence of cells that exclude this stain in the prostate has been demonstrated (Pascal et al., 2007). It should be remembered that over-expression of this type of $A B C$ transporters is responsible for drug resistance in most cancers (Stavrovskaya \& Stromskaya, 2008; Sharom, 2008).

\section{Hormone-resistance in prostate cancer}

Hormone-resistance in the prostate cancer is a clinical term that is often used for patients that have become refractory not only to androgen deprivation therapy, but also to other second-line hormonal treatments such as the use of estrogens (or analogues) (Mersenburger et al., 2008). However, the main change occurring at this stage is the androgen insensitivity. This phenomenon, as mentioned above, is not fully understood, but may occur for at least 2 mechanisms. The first is related to alterations in androgen receptor (AR), as amplifications, activating mutations, or mutations that make it sensitive to other androgens, such as adrenal androgens, or even other steroids such as cortisol (McPaul, 2008). In all these cases, the proliferation of tumor cells is still regulated by the AR activation. The second mechanism is independent of AR and occurs frequently in its absence, when the neoplastic cell becomes autocrine for other growth factors that control their proliferation (Lee \& Tenniswood, 2004). In either case, the patients no longer respond to androgen deprivation therapy and the prognosis is very unfavourable. Most of the available evidence suggests that the prostate CSCs would lack AR, which would make them intrinsically insensitive to androgens (Berry et al., 2008; Sharifi et al., 2008; Lowrance et al., 2015). This strongly suggests that these cells can contribute to the androgen resistance that is observed in late stages of prostate cancer, 
especially in the metastatic stage.

The most widely used treatments for androgen ablation therapy are surgical castration and, more recently, the use of GnRH analogues to block the hypothalamus-pituitary-gonad axis, thus reducing the gonadotropins level with subsequent inhibition of testicular testosterone (Suzuki et al., 2008; Kollmeier \& Zelefsky, 2008). It has been observed that patients treated with GnRH analogues have a longer survival than those undergoing surgical castration (Gnanapragasam et al., 2005). On the other hand, the presence of GnRH receptors ( $\mathrm{GnRH}$ $\mathrm{R}$ ) in tumor prostate cells has been reported (Finch et al., 2008; Montagnani Marelli et al., 2009). These evidences have led to propose a local effect for these analogues in addition to their androgen deprivation effect. In our laboratory, using a primary culture system of PCa cells, we have confirmed the presence of $\mathrm{GnRH}-\mathrm{R}$ and studied the local effect of GnRH analogues on the growth of these cell cultures (Castellón et al., 2006; Sánchez et al., 2005; Clementi et al., 2009). GnRH-R expressed in the prostate cancer cells has very similar antigenic, kinetics and binding characteristics to those displayed by the type I GnRH-R expressed in the gonadotroph cell (Castellón et al., 2006). Also, GnRH-R expressed by prostate cancer cells can be activated by both agonists (leuprolide) and antagonist (cetrorelix), and the result of this activation induces the apoptosis of cancer cells (Sánchez et al., 2005). This effect is mediated, at least in part, by the GnRH-Rdependent expression of apoptotic p75 NGF receptor and requires p53 phosphorylation (Clementi et al., 2009). In this work, we have also shown that the optimal concentration for the local effect of these analogues is beyond the concentration achieved in most treatments for androgen deprivation. One possibility to bypass this problem is the intraprostatic administration of these analogues. However, it has been observed that the expression of $\mathrm{GnRH}$ $R$ in samples of prostate cancer is variable and tends to decrease as the cancer becomes more aggressive (Szabó et al., 2009). This receptor, in normal conditions (gonadotroph cell), is retained almost $50 \%$ in the endoplasmic reticulum due to differences in its aminoacid sequence compared to other similar $\mathrm{G}$ protein coupled receptors (Janovick et al., 2003). It has been observed, in gonadotroph cell lines, that this retained amount of $\mathrm{GnRH}-\mathrm{R}$ can be rescued by special drugs called pharmacoperons (Leaños-Miranda et al., 2005; Janovick et al., 2009). In our laboratory, we are rescuing by pharmacoperons $\mathrm{GnRH}-\mathrm{R}$ in prostate cancer cells to increase the sensitivity of these cells to $\mathrm{GnRH}$ analogues. There is no information in the literature on the expression of $\mathrm{GnRH}-\mathrm{R}$ in prostate CSCs. If prostate CSCs would not express this receptor, they would be resistant both to androgen deprivation (no AR) and to the local effects of $\mathrm{GnRH}$ analogues, which could explain the behavior of patients with advanced prostate cancer regarding these treatments.

\section{Chemotherapy resistance in prostate cancer}

Until today, one of the most important therapeutic tools for cancer treatment is certainly chemotherapy (Kurokawa \& Sasako, 2008; Sherman, 2009; Alberts \& Wagman, 2008; Yamashiro \& Toi, 2008). This is based on the administration of one or more cytotoxic drugs that act preferentially on neoplastic cells in active proliferation. The most common drugs act on the cytoskeleton, as anti-metabolites or directly on the DNA (Risinger et al., 2009; Altaner, 2008). The chemotherapy protocols depend on the cancer type, their progression stage and patient characteristics. However, for prostate cancer, this therapy is rarely used because of its poor effectiveness (Michael et al., 2009). Only modest results have been obtained using docetaxel (Sundaram et al., 2009; Vaishampayan et al., 2009). This is mainly due to the prostate cancer shows a particularly high resistance to chemotherapeutic drugs (van Brussel \& Mickisch, 2003). Our laboratory has investigated this problem in patients' biopsies and primary cultures of tumor cells. We have shown that this phenomenon is due, at least in part, to the high expression of multi-drug resistance (MDR) proteins Gp-P (ABCB1), MRP1 (ABCC1) and LRP (Sánchez et al., 2009). Gp-P and MRP1 correspond to members of the $A B C$ (ATP Binding Cassette) transporters family that transport (actively and selectively) toxic substances, including chemotherapeutic drugs, out of the cell. In this study, we found that these three MDR proteins are expressed in biopsies of patients with prostate cancer, with the general trend to show a positive association between 
the expression level of these MDR proteins and the degree of tumor malignancy. However, we also observed heterogeneity of MDR protein expression within the patients. Thus, biopsies of similar histological grade showed areas of higher expression of MDR that are consistent with the increased expression of other markers of tumor malignancy (unpublished observation). In our cell culture experiments, we have demonstrated that high expression of these MDR proteins is coincident with a high survival rate after treatment with the respective chemotherapeutic drugs. We have also shown that prolonged treatments with these drugs induce a higher expression of MDR proteins and reduced drug sensitivity (acquired resistance) (Sánchez et al., 2009). Finally, we found that pharmacological inhibition and knock down of these proteins recovered, in part, the sensitivityof prostate cancer cells to the action of various chemotherapeutic drugs (Sánchez et al., 2011).

All the evidence indicates that the CSCs express high protein levels of the $A B C$ transporter family (in particular $A B C G 2$ ) (Patrawala et al., 2005; Zhou et al., 2001). It is improbably that prostate CSCs escape from this phenomenon (Mathew et al., 2009), on the contrary, considering the high intrinsic resistance of prostate cancer to chemotherapy and the results reported by our laboratory and others, in relation to MDR proteins expression and its association with sensitivity to chemotherapeutic drugs, it is highly likely that prostate CSCs are involved in this phenomenon in prostate cancer.

\section{Prostate cancer stem cells as new target for therapy}

It has accumulated sufficient evidence to postulate that the prostatic CSCs could represent a potential therapeutic target (Lang et al., 2009). In general, prostate CSCs have been involved with epithelial-mesenchymal transition (Hollier et al., 2009), the niche formation for metastases generation (Takao \& Tsujimura, 2008), the metastatic capacity as such (Kelly \& Yin, 2008; Drewa \& Styczynski, 2008) and could have some relevance in other diseases such as prostate benign hyperplasia (Isaacs, 2008). Considering that generation of a complete prostate from a single stem cell has been recently reported
(Leong et al., 2008), it is reasonable to suggest that a single prostatic CSCs could be sufficient to generate a new tumor, which might be of particular importance in the endocrine regulated cancers (Lichtenauer \& Beuschlein, 2009) such as prostate cancer. For these reasons, we consider of fundamental importance to study systematically the presence of prostatic CSCs in order to isolate and characterize them as potential therapeutic target for selective elimination. Taking into account that CSCs can be found still in established cell lines, we consider that our primary cell culture system from prostate adenocarcinoma (Castellón et al., 2005, 2006 ) is a suitable model for the proposed study.

We have isolated and characterized a CSCs population from tumor-derived cell cultures from PCa patients, using different mixed methods. We have obtained enriched cultures of CSCs expressing a consistent molecular signature displaying a CD133+/CD44+/ABCG2+/CD24-/ SOX2+/Oct3/4+/AR-/PSA-/CMYC+/KLF4+ pattern. This stem signature is very similar to that obtained from PCa cell lines, suggesting that prostate CSCs are very conservative.

Considering their properties, PCa CSCs might represent a potential therapeutic target (Lang et al.). We have evaluated the stem signature described in enriched population of CSCs from tumor explants, in representative biopsies of the different histological grades and lymph-node and bone metastasis samples. We have found that stem markers analysed were present in low, medium and high Gleason grades and metastasis. Interestingly, the highest expression of CSCs markers was found in medium Gleason grades (Castellon et al., 2006). These samples correspond to patients with medium Gleason score (grades 5 to 6 ). At this stage, the tumor is usually confined to the prostate gland and most patients are subjected to radical surgery. However, many of them (around $30 \%$ ) relapse months after surgery (Kotb \& Elabbady, 2011). This is a very interesting point, taking into account that metastasis is rather an inefficient process, because less than $1 \%$ of malignant cells reaching blood stream are able colonize distant tissues, and even a smaller percentage can induce metastases (Chiang \& Massagué). There are convincing evidence that primary tumor, 
produce and secrete signals (altered proteins) that affect, in a selective manner, to selective stromal tissue favouring CSCs premetastaticniche (Chiang \& Massagué; Witz). Once CSCs colonize these conditioned stromas, they may remain for long time in dormant state before activate and produce metastases (Kaplan et al., 2006; Wels et al.). This may explain the recurrence after intended curative surgery in many cancers. In $\mathrm{PCa}$, it is believed that radical surgery in localized tumors is curative. However, many cancer cells, at this point, may have reached blood stream (some of them presumably CSCs), colonized lymph nodes or other tissues and entered in dormant state. These CSCs may be responsible for later recurrence in those patients. On the other hand, lymph-node and bone metastasis displayed the lowest expression of CSCs markers. This suggests that in growing metastasis, progenitors and malignant differentiated cells (originated from CSCs) are predominant.

PCa CSCs have been associated to EMT (Hollier et al.), pre-metastatic niche preparation, recurrence and metastasis (Drewa \& Styczynski; Kelly \& Yin; Takao \& Tsujimura). At this respect, our results represent an important step in the efforts to further characterize CSCs from PCa in order to identify potential therapeutic targets for selective elimination. Considering that PCa CSCs have been studied mainly in established cell lines, our PCa tumor-derived culture system mat be a more suitable model for the study of CSCs. A further characterization of PCa CSCs using their ability to form tumorspheres has been carried out in our laboratory. Like in other models, ABCG2 transporter is highly expressed. In fact, this transporter has been used to isolate CSCs from many tumors (side population). In PCa tumorspheres, we have also found CK5 and CK18 expression. This is a very interesting finding since CK5 is expressed mainly in prostate basal cells (Miki, 2010) and it has been associated with invasiveness and metastasis in breast cancer (Sutton et al., 2010; de Silva et al., 2011). In addition, this cytokeratin expression has also been observed in $\mathrm{PCa}$ spheres (Garraway et al., 2010), suggesting a contribution of basal cells in CSCs population. The expression of epithelial marker CK18 strongly suggests that PCa CSCs may come from a divergence of the EMT process rather than a malignant transformation of normal prostate stem cell (Celia-Terrassa, et al., 2012). The absence of AR expression indicates that PCa CSCs represent an androgen-insensitive cell type within thePCa tumor. On the other hand, the low expression of PSA in prostatospheres may be the result of EMT. Our results on differential clonogenic capacity (mainly holoclones), anchorage-independent growth and self-renewal properties are consistent with the most important properties of stem cells (Miki; Patrawala et al., 2006, 2007). Additionally, low proliferation and apoptotic rate are common features of CSCs. The transporter ABCG2 is one of the most highly expressed in CSCs including our prostatosphere preparation. For this reason, we have assayed the resistance of PCa tumorspheres to chemotherapeutic drugs daunorubicin and topotecan (ABCG2 substrates). Our results showed that CSCs are significant more resistant than other cancer cells to ABCG2 transported drugs. In addition, the pharmacologic inhibitor of the ABCG2 transporter fumitremorgin $\mathrm{C}$, partially re-sensitizes, $\mathrm{PCa}$ tumorspheres to both drugs suggesting that ABCG2 transporter is involved in PCa drug resistance and could be a potential therapeutic target for CSCs-selective therapy.

\section{Projections}

The identification, characterization and pharmacological and gene manipulation of $\mathrm{PCa}$ CSCs would increase treatment sensitivCancer Stem Cells in Human Prostate Cancer. Role in Drug Resistance and Metastasis

Las células troncales del cáncer en el cáncer de próstata humano. Rol en la resistencia a los medicamentos y la metástasis.

CASTellón, E. A. \& CONTRERAS, H. R. Las Células Troncales del Cáncer en el Cáncer de Próstata Humano. Rol en la Resistencia a los Medicamentos y la Metástasis. Int. J. Med. Surg. Sci., 2(4):711-722, 2015.

RESUMEN: El cáncer de próstata es una de las causas más importantes de muerte oncológica en los hombres, y Chile también ha llegado a ese nivel. La mortalidad por cáncer de próstata se asocia sobre todo con la enfermedad metastásica en el que el cáncer suele ser resistente a los tratamientos disponibles, en particular la terapia hormonal y la quimiote- 
rapia. Se ha sugerido que la existencia de células troncales cancerígenas podría ser responsable de la capacidad metastásica y la resistencia al tratamiento en la mayoría de los cánceres. Recientemente, las células con características troncales han sido identificadas en las líneas celulares establecidas y modelos animales de cáncer de próstata. Hemos aislado y caracterizado este tipo de células en de tumores de pacientes. Este hallazgo abre la posibilidad de manipularlos como dianas terapéuticas potenciales.

PALABRAS CLAVE: Cáncer de próstata; Células troncales cancerígena; Resistencia a las drogas; Metástasis.

\section{REFERENCES}

Acloque, H.; Adams, M. S.; Fishwick, K.; BronnerFraser, M. \& Nieto, M. A. Epithelial-mesenchymal transitions: the importance of changing cell state in development and disease. J. Clin. Invest., 119(6): 1438-49 2009.

Alberts, S. R. \& Wagman, L. D. Chemotherapy for colorectal cancer liver metastases. Oncologist, 13(10): 1063-73, 2008.

Altaner, C. Prodrug cancer gene therapy. Cancer Lett., 270(2):191-201, 2008.

Berry, P. A. ; Maitland, N. J. \& Collins, A. T. Androgen receptor signalling in prostate: effects of stromal factors on normal and cancer stem cells. Mol. Cell. Endocrinol., 288(1-2):30-7, 2008.

Bonnet, D. \& Dick, J. E. Human acute myeloid leukemia is organized as a hierarchy that originates from a primitive hematopoietic cell. Nat. Med., 3(7):730-7, 1997.

Borst, P.; Jonkers, J.\& Rottenberg, S. What makes tumors multidrug resistant? Cel/ Cycle, 6(22):2782-7, 2007.

Cabanillas, R. \& Llorente, J. L. The Stem Cell Network model: clinical implications in cancer. Eur. Arch. Otorhinolaryngol., 266(2):161-70, 2009.

Castellón, E.; Clementi, M.; Hitschfeld, C.; S.nchez, C. ; Benítez, D.; Sáenz, L.; Contreras, H. \& Huidobro, C. Effect of leuprolide and cetrorelix on cell growth, apoptosis, and GnRH receptor expression in primary cell cultures from human prostate carcinoma. Cancer Invest., 24(3):261$8,2006$.
Castellón, E.; Venegas, K.; S·enz, L.; Contreras, H. \& Huidobro, C. Secretion of prostatic specific antigen, proliferative activity and androgen response in epithelial-stromal co-cultures from human prostate carcinoma. Int. J. Androl., 28(1):39-46, 2005.

Celia-Terrassa, T.; Meca-Cortés, O.; Mateo, F.; de Paz, A. M.; Rubio, N.; Arnal-Estapé, A.; Ell, B. J.; Bermudo, R.; Díaz, A.; Guerra-Rebollo, M. ; Lozano, J. J.; Estar.S, C.; Ulloa, C.; ilvarez-Simún, D.; Mila, J.; Vilella, R.; Paciucci, R.; MartínezBalb.s, M. ; de Herreros, A. G.; Gomis, R. R.; Kang, Y.; Blanco, J.; Fernández, P. L. \& Thomson, T. M. Epithelial-mesenchymal transition can suppress major attributes of human epithelial tumorinitiating cells. J. Clin. Invest., 122(5):1849-68, 2012.

Chiang, A. C. \& Massagué, J. Molecular basis of metastasis. N. Engl. J. Med., 359(26):2814-23, 2008.

Cifuentes, F. F.; Valenzuela, R. H.; Contreras, H. R. \& CastellÛn, E. A. Development of an orthotopic model of human metastatic prostate cancer in the NOD-SCIDY mouse (Mus musculus) anterior prostate. Oncol. Lett., 10(4):2142-8, 2015 a.

Cifuentes, F. F.; Valenzuela, R. H.; Contreras, H. R. \& Castellón, E. A. Surgical cytoreduction of the primary tumor reduces metastatic progression in a mouse model of prostate cancer. Oncol. Rep., Oct 1. doi: 10.3892/or.2015.4319. 2015b. [Epub ahead of print]

Clementi, M.; Sánchez, C.; Benitez, D. A.; Contreras, H. R.; Huidobro, C.; Cabezas, J.; Acevedo, C. \& Castellón, E. A. Gonadotropin releasing hormone analogs induce apoptosis by extrinsic pathway involving p53 phosphorylation in primary cell cultures of human prostatic adenocarcinomas. Prostate, 69(10):1025-33, 2009.

Contreras, H. R.; Ledezma, R. A. ; Vergara, J.; Cifuentes, F.; Barra, C.; Cabello, P.; Gallegos, I.; Morales, B.; Huidobro, C. \& Castellon, E. A. The expression of syndecan-1 and -2 is associated with Gleason score and epithelial-mesenchymal transition markers, Ecadherin and beta-catenin, in prostate cancer. Urol. Oncol., 28(5):534-40, 2010.

de Silva Rudland, S.; Platt-Higgins, A.; Winstanley, J. H.; Jones, N. J.; Barraclough, R.; West, C.; Carroll, J. \& Rudland, P. S. Statistical association of basal cell keratins with metastasis-inducing proteins in a prognostically unfavorable group of sporadic breast cancers. Am. J. Pathol., 179(2):1061-72, 2011. 
Di Zazzo, E. ; Galasso, G. ; Giovannelli, P.; Di Donato, M.; Di Santi A, Cernera, G.; Rossi, V.; Abbondanza, C.; Moncharmont, B.; Sinisi, A. A.; Castoria, G. \& Migliaccio, A. Prostate cancer stem cells: the role of androgen and estrogen receptors. Oncotarget, doi: 10.18632/ oncotarget.6220, 2015. [Epub ahead of print]

Drewa, T. \& Styczynski, J. Can conception of prostate cancer stem cells influence treatment dedicated to patients with disseminated disease? Med. Hypotheses, 71(5):694-9, 2008.

Filip, S.; Mokry, J.; Horacek, J. \& English, D. Stem cells and the phenomena of plasticity and diversity: a limiting property of carcinogenesis. Stem Cells Dev., 17(6):1031-8, 2008.

Finch, A. R.; Sedgley, K. R. ; Caunt, C. J. \& McArdle, C. A. Plasma membrane expression of $\mathrm{GnRH}$ receptors: regulation by antagonists in breast, prostate, and gonadotrope cell lines. J. Endocrinol., 196(2):353-67, 2008.

Fioriti, D.; Mischitelli, M.; Di Monaco, F.; Di Silverio, F.; Petrangeli, E.; Russo, G.; Giordano, A. \& Pietropaolo, V. Cancer stem cells in prostate adenocarcinoma: a target for new anticancer strategies. J. Cell. Physiol., 216(3):571-5, 2008.

Gao, J. X. Cancer stem cells: the lessons from precancerous stem cells. J. Cell. Mol. Med., 12(1):6796, 2008.

Garraway, I. P.; Sun, W.; Tran, C. P.; Perner, S.; Zhang, B.; Goldstein, A. S.; Hahm, S. A.; Haider, M.; Head, C. S.; Reiter, R. E.; Rubin, M. A. \& Witte, O. N. Human prostate sphere-forming cells represent a subset of basal epithelial cells capable of glandular regeneration in vivo. Prostate, 70(5):491-501, 2010.

Gil, J.; Stembalska, A.; Pesz, K. A. \& Sasiadek, M. M. Cancer stem cells: the theory and perspectives in cancer therapy. J. App. Genet., 49(2):193-9, 2008.

Glinsky, G. V. "Stemness" genomics law governs clinical behavior of human cancer: implications for decision making in disease management. $J$. Clin. Oncol., 26(17):2846-53, 2008.

Gnanapragasam, V. J.; Darby, S. ; Khan, M. M. ; Lock, W. G.; Robson, C. N. \& Leung, H. Y. Evidence that prostate gonadotropin-releasing hormone receptors mediate an anti-tumourigenic response to analogue therapy in hormone refractory prostate cancer. J. Pathol., 206(2):205-13, 2005.

International Agency for Research of Cancer. Globocan. Geneve, World Health Organization,
2012. Disponible en: http://globocan.iarc.fr/ Pages/fact_sheets_cancer.aspx

Hollier, B. G.; Evans, K. \& Mani, S. A. The epithelialto-mesenchymal transition and cancer stem cells: a coalition against cancer therapies. J. Mammary Gland. Biol. Neoplasia, 14(1):29-43, 2009.

Isaacs, J. T. Prostate stem cells and benign prostatic hyperplasia. Prostate, 68(9):1025-34, 2008.

Ishii, H. ; Iwatsuki, M. ; Ieta, K. ; Ohta, D. ; Haraguchi, N.; Mimori, K. \& Mori, M. Cancer stem cells and chemoradiation resistance. Cancer Sci., 99(10): 1871-7, 2008.

Janovick, J. A.; Patny, A.; Mosley, R.; Goulet, M. T.; Altman, M. D. ; Rush, T. S. 3rd.; Cornea, A. \& Conn, P. M. Molecular mechanism of action of pharmacoperone rescue of misrouted GPCR mutants: the $\mathrm{GnRH}$ receptor. Mol. Endocrinol., 23(2): 157-68, 2009.

Janovick, J. A.; Ulloa-Aguirre, A. \& Conn, P. M. Evolved regulation of gonadotropin-releasing hormone receptor cell surface expression. Endocrine, 22(3):317-27, 2003.

Kaplan, R. N.; Psaila, B. \& Lyden, D. Bone marrow cells in the 'pre-metastatic niche': within bone and beyond. Cancer Metastasis Rev., 25(4):521-9, 2006.

Kasper, S. Stem cells: The root of prostate cancer? J. Cell. Physiol., 216(2):332-6, 2008.

Kelly, K. \& Yin, J. J. Prostate cancer and metastasis initiating stem cells. Cell Res., 18(5):528-37, 2008.

Kollmeier, M. A. \& Zelefsky, M. J. What is the role of androgen deprivation therapy in the treatment of locally advanced prostate cancer? Nat. Clin. Pract. Urol., 5(11):584-5, 2008

Kotb, A. F. \& Elabbady, A. A. Prognostic factors for the development of biochemical recurrence after radical prostatectomy. Prostate Cancer, 2011:485189, 2011.

Kurokawa, Y. \& Sasako, M. Recent advances in chemotherapy and chemoradiotherapy for gastrointestinal tract cancers: adjuvant chemoradiotherapy for gastric cancer. Int. J. Clin. Oncol., 13(6):479-82, 2008.

Lang, S. H.; Frame, F. M. \& Collins, A. T. Prostate cancer stem cells. J. Pathol., 217(2):299-306, 2009. 
Lapidot, T.; Sirard, C.; Vormoor, J.; Murdoch, B.; Hoang, T.; Caceres-Cortes, J.; Minden, M.; Paterson, B.; Caligiuri, M. A. \& Dick, J. E. A cell initiating human acute myeloid leukaemia after transplantation into SCID mice. Nature, 367(6464):645-8, 1994.

Le Tourneau, C.; Faivre, S. \& Raymond, E. New developments in multitargeted therapy for patients with solid tumours. Cancer Treat. Rev., 34(1):37-48, 2008.

Leaños-Miranda, A.; Ulloa-Aguirre, A.; Janovick, J. A. \& Conn, P. M. In vitro coexpression and pharmacological rescue of mutant gonadotropinreleasing hormone receptors causing hypogonadotropic hypogonadism in humans expressing compound heterozygous alleles. J. Clin. Endocrinol. Metab., 90(5):3001-8, 2005.

Lee, E. C. \& Tenniswood, M. P. Emergence of metastatic hormone-refractory disease in prostate cancer after anti-androgen therapy. J. Cell. Biochem., 91(4):662-70, 2004.

Leong, K. G.; Wang, B. E.; Johnson, L. \& Gao, W. Q. Generation of a prostate from a single adult stem cell. Nature, 456(7223):804-8, 2008.

Lewis, M. T. Faith, heresy and the cancer stem cell hypothesis. Future Oncol., 4(5):585-9, 2008.

Lichtenauer, U. D. \& Beuschlein, F. The tumor stem cell concept-implications for endocrine tumors? Mol. Cell. Endocrinol., 300(1-2):158-63, 2009.

Lobo, N. A.; Shimono, Y.; Qian, D. \& Clarke, M. F. The biology of cancer stem cells. Annu. Rev. Cell Dev. Biol., 23:675-99, 2007.

Lowrance, W. T.; Roth, B. J. ; Kirkby, E. ; Murad, M. H. \& Cookson, M. S. Castration-Resistant Prostate Cancer: AUA Guideline Amendment 2015. J. Urol., pii:S0022-5347(15)05026-0, 2015.

Maitland, N. J. \& Collins, A. T. Prostate cancer stem cells: a new target for therapy. J. Clin. Oncol., 26(17):2862-70, 2008.

Masters, J. R.; Kane, C.; Yamamoto, H. \& Ahmed, A. Prostate cancer stem cell therapy: hype or hope? Prostate Cancer Prostatic Dis., 11(4):3169, 2008.

Mathew, G.; Timm, E. A. Jr.; Sotomayor, P.; Godoy, A.; Montecinos, V. P.; Smith, G. J. \& Huss, W. J. ABCG2-mediated DyeCycle Violet efflux defined side population in benign and malignant prostate. Cell Cycle, 8(7):1053-61, 2009.
McPhaul, M. J. Mechanisms of prostate cancer progression to androgen independence. Best Pract. Res. Clin. Endocrinol. Metab., 22(2):37388, 2008.

Merseburger, A. S.; Belka, C.; Behmenburg, K. \& Stenzl, A. Secondary hormonal manipulation. Front. Radiat. Ther. Oncol., 41:93-102, 2008.

Michael, A.; Syrigos, K. \& Pandha, H. Prostate cancer chemotherapy in the era of targeted therapy. Prostate Cancer Prostatic Dis., 12(1):13-6, 2009.

Miki, J. \& Rhim, J. S. Prostate cell cultures as in vitro models for the study of normal stem cells and cancer stem cells. Prostate Cancer Prostatic Dis., 11(1):32-9, 2008.

Miki, J. Investigations of prostate epithelial stem cells and prostate cancer stem cells. Int. J. Urol., 17(2):139-47, 2010.

Departamento de Estadísticas e Información de Salud (DEIS). Mortalidad. Santiago de Chile, Ministerio de Salud (MINSAL), Departamento de Estadísticas e Información de Salud (DEIS), 2015. Disponible en: http://www.deis.cl/ $? p=51$

Montagnani Marelli, M.; Moretti, R. M.; Mai, S.; Januszkiewicz-Caulier, J.; Motta, M. \& Limonta, P. Type I gonadotropin-releasing hormone receptor mediates the antiproliferative effects of GnRH-II on prostate cancer cells. J. Clin. Endocrinol. Metab., 94(5):1761-7, 2009.

Nelson, W. G. ; De Marzo, A. M. \& Isaacs, W. B. Prostate cancer. N. Engl. J. Med., 349(4):366-81, 2003.

Pardal, R.; Clarke, M. F. \& Morrison, S. J. Applying the principles of stem-cell biology to cancer. Nat. Rev. Cancer, 3(12):895-902, 2003.

Pascal, L. E.; Oudes, A. J.; Petersen, T. W.; Goo, Y. A.; Walashek, L. S.; True, L. D. \& Liu, A. Y. Molecular and cellular characterization of ABCG2 in the prostate. B. M. C. Urol., 7:6, 2007.

Patrawala, L.; Calhoun, T.; Schneider-Broussard, R.; Li, H. ; Bhatia, B. ; Tang, S. ; Reilly, J. G. ; Chandra, D.; Zhou, J.; Claypool, K.; Coghlan, L. \& Tang, D. G. Highly purified CD44+ prostate cancer cells from xenograft human tumors are enriched in tumorigenic and metastatic progenitor cells. Oncogene, 25(12):1696-708, 2006.

Patrawala, L.; Calhoun, T.; Schneider-Broussard, R.; Zhou, J.; Claypool, K. \& Tang, D. G. Side 
population is enriched in tumorigenic, stem-like cancer cells, whereas ABCG2+ and ABCG2- cancer cells are similarly tumorigenic. Cancer Res., 65(14):6207-19, 2005.

Patrawala, L.; Calhoun-Davis, T.; SchneiderBroussard, R. \& Tang, D. G. Hierarchical organization of prostate cancer cells in xenograft tumors: the CD44+alpha2beta1+ cell population is enriched in tumor-initiating cells. Cancer Res., 67(14):6796-805, 2007.

Poblete, C. E.; Fulla, J.; Gallardo, M.; Muñoz, V.; CastellÛn, E. A.; Gallegos, I. \& Contreras, H. R. Increased SNAIL expression and low syndecan levels are associated with high Gleason grade in prostate cancer. Int. J. Oncol., 44(3):647-54, 2014.

Reya, T.; Morrison, S. J.; Clarke, M. F. \& Weissman, I. L. Stem cells, cancer, and cancer stem cells. Nature, 414(6859):105-11, 2001.

Risinger, A. L.; Giles, F. J. \& Mooberry, S. L. Microtubule dynamics as a target in oncology. Cancer Treat. Rev., 35(3):255-61, 2009.

Roussel, B.; Ouellet, G. M.; Mohile, S. G. \& Dale, W. Prostate Cancer in Elderly Men: Screening, Active Surveillance, and Definitive Therapy. Clin. Geriatr. Med., 31(4):615-29, 2015.

Sánchez, C.; Mercado, A.; Contreras, H. R. ; Mendoza, P.; Cabezas, J.; Acevedo, C.; Huidobro, C. \& Castellón, E. A. Chemotherapy sensitivity recovery of prostate cancer cells by functional inhibition and knock down of multidrug resistance proteins. Prostate, 71(16):1810-7, 2011.

Sánchez, C.; Clementi, M.; Benitez, D.; Contreras, H. ; Huidobro, C. \& Castelon, E. Effect of GnRH analogs on the expression of TrkA and p75 neurotrophin receptors in primary cell cultures from human prostate adenocarcinoma. Prostate, 65(3): 195-202, 2005.

Sánchez, C.; Mendoza, P.; Contreras, H. R.; Vergara, J.; McCubrey, J. A.; Huidobro, C. \& Castellon, E. A. Expression of multidrug resistance proteins in prostate cancer is related with cell sensitivity to chemotherapeutic drugs. Prostate, 69(13):1448$59,2009$.

Shah, R. B.; Mehra, R.; Chinnaiyan, A. M.; Shen, R. ; Ghosh, D. ; Zhou, M.; Macvicar, G. R.; Varambally, S. ; Harwood, J.; Bismar, T. A.; Kim, R.; Rubin, M. A. \& Pienta, K. J. Androgen-independent prostate cancer is a heterogeneous group of diseases: lessons from a rapid autopsy program. Cancer Res., 64(24):9209-16, 2004.
Sharifi, N.; Hurt, E. M. \& Farrar, W. L. Androgen receptor expression in prostate cancer stem cells: is there a conundrum? Cancer Chemother. Pharmacol., 62(5):921-3, 2008.

Sharom, F. J. ABC multidrug transporters: structure, function and role in chemoresistance. Pharmacogenomics, 9(1):105-27, 2008.

Sherman, S. I. Advances in chemotherapy of differentiated epithelial and medullary thyroid cancers. J. Clin. Endocrinol. Metab., 94(5):14939, 2009.

Shipitsin, M. \& Polyak, K. The cancer stem cell hypothesis: in search of definitions, markers, and relevance. Lab. Invest., 88(5):459-63, 2008.

Stavrovskaya, A. A. \& Stromskaya, T. P. Transport proteins of the $A B C$ family and multidrug resistance of tumor cells. Biochemistry (MosC.), 73(5):592-604, 2008.

Sundaram, S.; Durairaj, C.; Kadam, R. \& Kompella, $U$. B. Luteinizing hormone-releasing hormone receptor-targeted deslorelin-docetaxel conjugate enhances efficacy of docetaxel in prostate cancer therapy. Mol. Cancer Ther., 8(6): 1655-65, 2009.

Sutton, L. M.; Han, J. S.; Molberg, K. H.; Sarode, V. R.; Cao, D.; Rakheja, D.; Sailors, J. \& Peng, Y. Intratumoral expression level of epidermal growth factor receptor and cytokeratin $5 / 6$ is significantly associated with nodal and distant metastases in patients with basal-like triple-negative breast carcinoma. Am. J. Clin. Pathol., 134(5):782-87, 2010.

Suzuki, H. ; Kamiya, N.; Imamoto, T.; Kawamura, K. ; Yano, M.; Takano, M.; Utsumi, T.; Naya, Y. \& Ichikawa, T. Current topics and perspectives relating to hormone therapy for prostate cancer. Int. J. Clin. Oncol., 13(5):401-10, 2008.

Szabó, J.; Bartók, K.; Krencs, T.; Szepesvry, Z. \& Szende, B. GnRH receptor and androgen receptor status and outcome of advanced prostate carcinomas. Anticancer Res., 29(2):681-4, 2009.

Takao, T. \& Tsujimura, A. Prostate stem cells: the niche and cell markers. Int. J. Urol., 15(4):28994, 2008.

Tang, D. G.; Patrawala, L.; Calhoun, T.; Bhatia, B.; Choy, G.; Schneider-Broussard, R. \& Jeter, C. Prostate cancer stem/progenitor cells: identification, characterization, and implications. Mol. Carcinog., 46(1):1-14, 2007. 
Timms, B. G. Prostate development: a historical perspective. Differentiation, 76(6):565-77, 2008.

Vaishampayan, U. N.; Marur, S.; Heilbrun, L.K.; Cher, M. L.; Dickow, B.; Smith, D. W. ; Al Hasan, S. A.; Eliason, J. \& Phase II trial of capecitabine and weekly docetaxel for metastatic castrate resistant prostate cancer. J. Urol., 182(1):317-23, 2009.

van Brussel, J. P. \& Mickisch, G. H. Multidrug resistance in prostate cancer. Onkologie, 26(2):175-81, 2003.

Van Poppel, H.; Joniau, S.; Van Cleynenbreugel, B.; Mottaghy, F. M. \& Oyen, R. Diagnostic evaluation of PSA recurrence and review of hormonal management after radical prostatectomy. Prostate Cancer Prostatic Dis., 12(2):116-23, 2009.

Ward, R. J. \& Dirks, P. B. Cancer stem cells: at the headwaters of tumor development. Annu. Rev. Pathol., 2:175-89, 2007.

Wels, J.; Kaplan, R. N.; Rafii, S. \& Lyden, D. Migratory neighbors and distant invaders: tumor-associated niche cells. Genes Dev., 22(5):559-74, 2008.

Witz, I. P. Tumor-microenvironment interactions: dangerous liaisons. Adv. Cancer Res., 100:20329, 2008.

Yamashiro, H. \& Toi, M. Update of evidence in chemotherapy for breast cancer. Int. J. Clin. Oncol., 13(1):3-7, 2008.
Zhou, S.; Schuetz, J. D.; Bunting, K. D.; Colapietro, A. M.; Sampath, J.; Morris, J. J.; Lagutina, I.; Grosveld, G. C.; Osawa, M.; Nakauchi, H. \& Sorrentino, B. P. The ABC transporter Bcrp1/ ABCG2 is expressed in a wide variety of stem cells and is a molecular determinant of the sidepopulation phenotype. Nat. Med., 7(9):1028-34, 2001.

Correspondence to:

Enrique A. Castellón, Ph.D.

Laboratory of Molecular and Cellular Andrology

Physiology and Biophysics Program

Institute of Biomedical Sciences

Faculty of Medicine

Universidad de Chile

Independencia 1027

Postal code: 8380453

Santiago

CHILE

Phone: 56-2-978 6861.

Fax: 56-2-777 6916.

Email: ecastell@med.uchile.cl.

Received: 08-11-2015

Accepted: 02-12-2015 